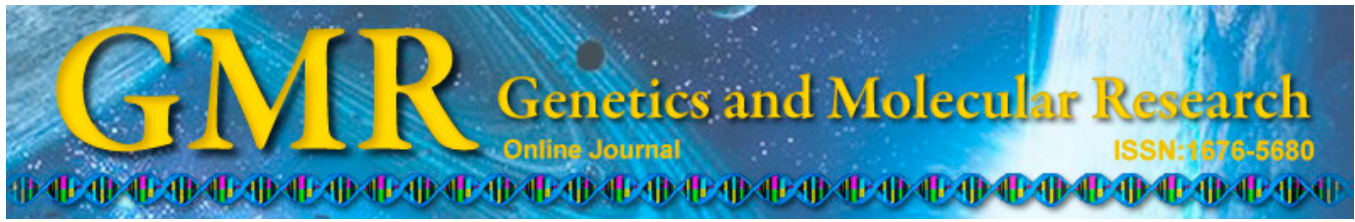

\title{
Unraveling systematic inventory of Echinops (Asteraceae) with special reference to nrDNA ITS sequence-based molecular typing of Echinops abuzinadianus
}

\author{
M.A. Ali ${ }^{1}$, F.M. Al-Hemaid ${ }^{1}$, J. Lee ${ }^{2}$, A.A. Hatamleh ${ }^{1}$, G. Gyulai ${ }^{3}$ and \\ M.O. Rahman ${ }^{4}$ \\ ${ }^{1}$ Department of Botany and Microbiology, College of Science, \\ King Saud University, Riyadh, Saudi Arabia \\ ${ }^{2}$ Department of Environment and Forest Resources, \\ Chungnam National University, Yuseong-gu, \\ Daejeon, Republic of Korea \\ ${ }^{3}$ Institute of Genetics and Biotechnology, St. István University, \\ Gödöllo, Hungary \\ ${ }^{4}$ Department of Botany, University of Dhaka, Dhaka, Bangladesh
}

Corresponding author: M.A. Ali

E-mail: alimohammad@ksu.edu.sa

Genet. Mol. Res. 14 (4): 11752-11762 (2015)

Received January 30, 2015

Accepted May 25, 2015

Published October 2, 2015

DOI http://dx.doi.org/10.4238/2015.October.2.9

ABSTRACT. The present study explored the systematic inventory of Echinops L. (Asteraceae) of Saudi Arabia, with special reference to the molecular typing of Echinops abuzinadianus Chaudhary, an endemic species to Saudi Arabia, based on the internal transcribed spacer (ITS) sequences (ITS1-5.8S-ITS2) of nuclear ribosomal DNA. A sequence similarity search using BLAST and a phylogenetic analysis of the ITS sequence of E. abuzinadianus revealed a high level of sequence similarity with E. glaberrimus DC. (section Ritropsis). The novel primary sequence and the secondary structure 
of ITS2 of E. abuzinadianus could potentially be used for molecular genotyping.

Key words: Echinops abuzinadianus; Asteraceae; Endemic species; Saudi Arabia; Internal transcribed spacer

\section{INTRODUCTION}

The genus Echinops L. (subtribe Echinopsinae of Cynareae, family Asteraceae) consists of ca. 120 species (Bobrov, 1997; Susanna and Garcia-Jacas, 2007) that are distributed in tropical Africa, the Mediterranean basin, temperate regions of Eurasia, Central Asia, Mongolia, and north-eastern China, with most occurring in the Caucasus and the Middle East (Jäger, 1987; Sánchez-Jiménez et al., 2010). The key taxonomic characteristics of the Cynareae, such as the pappus and the type and density of the indumentum on the stems, leaves, and phyllaries, cannot easily be used to distinguish between Echinops species (Mozaffarian, 2006; Sánchez-Jiménez et al., 2010).

In Saudi Arabia, Echinops L. is represented by 10 species: E. abuzinadianus Chaudhary, E. erinaceus Kit-Tan, E. glaberrimus DC., E. hystrichoides Kit-Tan, E. macrochaetus Fresen, E. mandavillei Kit-Tan, E. polyceras Boiss., E. sheilae Kit-Tan, E. viscosus DC., and E. yemenicus Kit-Tan. Of these, E. abuzinadianus, E. mandavillei, and E. sheilae are endemic to Saudi Arabia (Chaudhary, 2000).

Since the first report of the utility of internal transcribed spacer (ITS) sequences of nuclear ribosomal DNA (nrDNA) in plants (Baldwin, 1992), the nuclear ribosomal ITS region (nrITS) has revolutionized species-level plant phylogenetics, because evolution has generally homogenized sequence variation among the numerous ribosomal DNA copies within an individual, making direct sequencing of this region possible for most systems. This, coupled with the availability of universal primers and elevated substitution rates compared to most chloroplast regions, make it accessible and appropriate for resolving interspecific phylogenetic relationships. Although reliance on nrITS as the sole source of phylogenetic evidence has come under criticism because of certain features of its evolution, it remains the most efficient locus for generating species-level phylogenetic inferences in most plant groups (Ali et al., 2013, 2014). The ITS region has been chosen previously for investigating the molecular phylogeny of Echinops (Garnatje et al., 2005; Al-Hemaid et al., 2014) and other genera of Cynareae (Susanna et al., 1999; Vilatersana et al., 2000; Hidalgo et al., 2006; Wang et al., 2005, 2007). The present study aimed to unravel the systematic inventory of Saudi Arabian Echinops, with special reference to the nrDNA ITS sequence-based molecular genotyping of the endemic species, E. abuzinadianus.

\section{MATERIAL AND METHODS}

\section{Taxon sampling}

Leaf material of E. abuzinadianus was collected from a herbarium specimen housed at the National Herbarium and Genbank, National Agriculture and Animal Resources Research Center, Riyadh, Saudi Arabia, and the taxonomic identification was confirmed after consulting the Flora of Saudi Arabia (Chaudhary, 2000). Information on taxonomic status, protolog 
(http://www.theplantlist.org/), distribution (Chaudhary, 2000), and nucleotides (http://www. ncbi.nlm.nih.gov/) was also collected.

\section{Genomic DNA isolation, amplification and sequencing}

Total genomic DNA was extracted using a DNeasy Plant Mini Kit (Qiagen, Valencia, CA, USA). The nrDNA ITS regions were amplified using the primers ITS1 and ITS4 (White et al., 1990). A DNA amplification for 35 cycles was conducted by polymerase chain reaction (PCR). The PCR products were purified using a SolGent PCR Purification Kit-Ultra (SolGent, Daejeon, South Korea). Sequencing was conducted using a BigDye ${ }^{\circledR}$ Terminator cycle sequencing kit (Applied Biosystems, USA) and an ABI 3100 Avant capillary sequencer (Applied Biosystems).

\section{Phylogenetic analyses}

The sequences were performed by BLAST in GenBank (http://blast.ncbi.nlm.nih.gov/ Blast.cgi) and edited using the ABI Sequence Navigator (Perkin-Elmer/Applied Biosystems). Sequence alignment was performed using Clustal X, version 1.81 (Thompson et al., 1997), and subsequently manually adjusted using BioEdit (Hall, 1999).

The ITS sequences of nrDNA from 18 species of Echinops were retrieved from GenBank (Table 1). Two species were chosen as outgroup members [Brachylaena discolor DC. from the tribe Tarchonantheae Kostel and Cardopatium corymbosum (L.) Pers. from the subtribe Cardopatiinae Less.] according to previous study based on their morphological (Petit, 1988) and molecular characteristics (Susanna et al., 2006; Sánchez-Jiménez et al., 2010) (Table 1). Gaps were treated as missing data, and the generated sequences were submitted to GenBank. The boundaries between the ITS1-5.8S and ITS2 gene for E. abuzinadianus were determined according to the span referred to features of Echinops nrDNA ITS sequences available in GenBank. The ITS2 sequence was extracted from the complete set of the ITS sequences, and used in secondary structure prediction using tools from the ITS2 database (Koetschan et al., 2012). The aligned data matrix was exported as a nexus file and subsequently analyzed using maximum likelihood (ML) in MEGA5 (Tamura et al., 2011).

\section{RESULTS}

\section{Systematic inventory}

E. abuzinadianus Chaudhary: Taxonomic Status: Accepted name (http://www. theplantlist.org/tpl1.1/record/gcc-120839); Protolog: Fl. Kingdom Saudi Arabia 2(3): 198, 418 (2000); Distribution: Saudi Arabia; Type Information: Collector: Chaudhary, Locality: Near Abha, Collection Date: 1981-11-17; GenBank Nucleotide: No record.

E. erinaceus Kit-Tan: Taxonomic Status: Accepted name (http://www.theplantlist.org/ tp11.1/record/gcc-2642); Protolog: Ann. Bot. Fenn. 32(2): 124 (1995); Distribution: Oman, Saudi Arabia, and South Yemen; GenBank Nucleotide: No record.

E. glaberrimus DC.: Taxonomic Status: Accepted name (http://www.theplantlist.org/ tp11.1/record/gcc-4375); Protolog: Ann. Sci. Nat., Bot., ser. 2, 2: 260 (1834); Distribution: 
Saudi Arabia; GenBank Nucleotide: GU134559 (voucher W2004-13486 tRNA-Leu (trnL) gene and trnL-trnF intergenic spacer, partial sequence; chloroplast), GU116509 (isolate W2004-13486 ITS1-5.8S ribosomal RNA gene, and ITS2, complete sequence).

Table 1. Plant accessions used for the molecular phylogenetic analysis of Echinops.

\begin{tabular}{|c|c|c|}
\hline & Taxa & GenBank accession No. \\
\hline \multicolumn{3}{|c|}{ Ingroup } \\
\hline \multirow[b]{2}{*}{1} & sect. Acantholepis (Less.) Jaub. \& Spach & \\
\hline & $\begin{array}{l}\text { E. acantholepis Jaub. \& Spach } \\
\text { sect. Chamaechinops Bunge }\end{array}$ & AY8262223 \\
\hline 2 & E. fastigiatus Kamelin \& Tscherneva & GU116503 \\
\hline 3 & E. humilis M. Bieb & GU116514 \\
\hline 4 & $\begin{array}{l}\text { E. integrifolius Kar. \& Kir } \\
\text { sect. Echinops L. }\end{array}$ & GU116517 \\
\hline 5 & E. freitagii Rech. f. & GU116504 \\
\hline 6 & $\begin{array}{l}\text { E. kotschyi Boiss. } \\
\text { sect. Hamolepis R.E. Fr. }\end{array}$ & GU116520 \\
\hline 7 & $\begin{array}{l}\text { E.hoehnelii Schweinf } \\
\text { sect. Hololeuce Rech. f. }\end{array}$ & GU116506 \\
\hline 8 & $\begin{array}{l}\text { E. hololeucus Rech. f. } \\
\text { sect. Nanechinops Bunge }\end{array}$ & GU116513 \\
\hline 9 & $\begin{array}{l}\text { E. gmelini Turcz. } \\
\text { sect. Oligolepis Bunge }\end{array}$ & GU116510 \\
\hline 10 & E. cornigerus DC. & GU116552 \\
\hline 11 & E. echinatus Roxb. & GU116497 \\
\hline 12 & $\begin{array}{l}\text { E. lipskyi Iljin } \\
\text { sect. Phaeochaete Bunge }\end{array}$ & GU116523 \\
\hline 13 & $\begin{array}{l}\text { E. longifolius A. Rich } \\
\text { sect. Psectra } \text { Endl. }\end{array}$ & GU116524 \\
\hline \multirow[t]{2}{*}{14} & $\begin{array}{l}\text { E. strigosus L. } \\
\text { sect. Ritropsis Greuter \& Rech. f. }\end{array}$ & AY5386532 \\
\hline & E. dichrous Boiss. \& Hausskn. & GU116495 \\
\hline 16 & E. endotrichus Rech. f. & GU116500 \\
\hline 17 & $\begin{array}{l}\text { E. glaberrimus DC. } \\
\text { sect. Terma Endl. }\end{array}$ & GU116509 \\
\hline 18 & E. exaltatus Schrad. & GU116501 \\
\hline \multicolumn{3}{|c|}{ Outgroup } \\
\hline 19 & Brachylaena discolor $\mathrm{DC}$. & AY8262363 \\
\hline 20 & Cardopatium corymbosum (L.) Pers. & AY8262383 \\
\hline
\end{tabular}

E. hystrichoides Kit-Tan: Taxonomic Status: Accepted name (http://www.theplantlist. org/tp11.1/record/gcc-138093); Protolog: Ann. Bot. Fenn. 32(2): 124 (1995); Distribution: Saudi Arabia and North Yemen; GenBank Nucleotide: GU134570 (voucher BC-Hein3942 tRNA-Leu (trnL) gene and trnL-trnF intergenic spacer, partial sequence; chloroplast), GU116515 (isolate BC-Hein3942 ITS1-5.8S ribosomal RNA gene, and ITS2, complete sequence).

E. macrochaetus Fresen: Taxonomic Status: Accepted name (http://www.theplantlist. org/tp11.1/record/gcc-129388); Protolog: Museum Senckenbergianum 3: 69 (1840); Distribution: Saudi Arabia; GenBank Nucleotide: No record.

E. mandavillei Kit-Tan: Taxonomic Status: Accepted name (http://www.theplantlist. org/tpl1.1/record/gcc-10419); Protolog: Ann. Bot. Fenn. 32(2): 122 (1995); Distribution: Saudi Arabia; GenBank Nucleotide: KJ187107 (ITS-1, partial sequence; 5.8S ribosomal RNA gene, complete sequence; and ITS2, partial sequence).

E. polyceras Boiss.: Taxonomic Status: Accepted name (http://www.theplantlist.org/ tp11.1/record/gcc-34304); Protolog: Diagn. Pl. Orient. ser. 1, 10: 85 (1849) [Mar-Apr 1849]; Distribution: Saudi Arabia; GenBank Nucleotide: No record. 
E. sheilae Kit-Tan: Taxonomic Status: Accepted name (http://www.theplantlist.org/ tp11.1/record/gcc-52766): Protolog: Ann. Bot. Fenn. 32(2): 118 (1995); Distribution: Saudi Arabia; GenBank Nucleotide: No record.

E. viscosus DC.: Taxonomic Status: Synonym of E. sphaerocephalus L. (http://www. theplantlist.org/tp11.1/record/gcc-106683); Protolog: Fl. Germ. Excurs. 856: Distribution: Saudi Arabia; GenBank Nucleotide: No record.

E. yemenicus Kit-Tan: Taxonomic Status: Accepted name (http://www.theplantlist. org/tpl1.1/record/gcc-107827); Protolog: Ann. Bot. Fenn. 32(2): 118 (1995); Distribution: North Yemen; GenBank Nucleotide: GU134616 (voucher BC-Hein3806 tRNA-Leu (trnL) gene and trnL-trnF intergenic spacer, partial sequence; chloroplast), GU116548 (isolate BCHein3806 ITS1-5.8S ribosomal RNA gene, and ITS2, complete sequence).

\section{Sequence characteristics and phylogenetic analyses}

The combined length of the ITS region (ITS1-5.8S-ITS2) in E. abuzinadianus was $634 \mathrm{bp}$ (Figure 1). The ITS1 region was 252 bp long (GC content 55\%), the $5.8 \mathrm{~S}$ gene was $164 \mathrm{bp}$ long (GC content 54\%), and the ITS2 region was 219 bp long (GC content 53\%). A BLAST of the ITS sequence of E. abuzinadianus indicated maximum identity (99\%) with $E$. glaberrimus (Table 2).

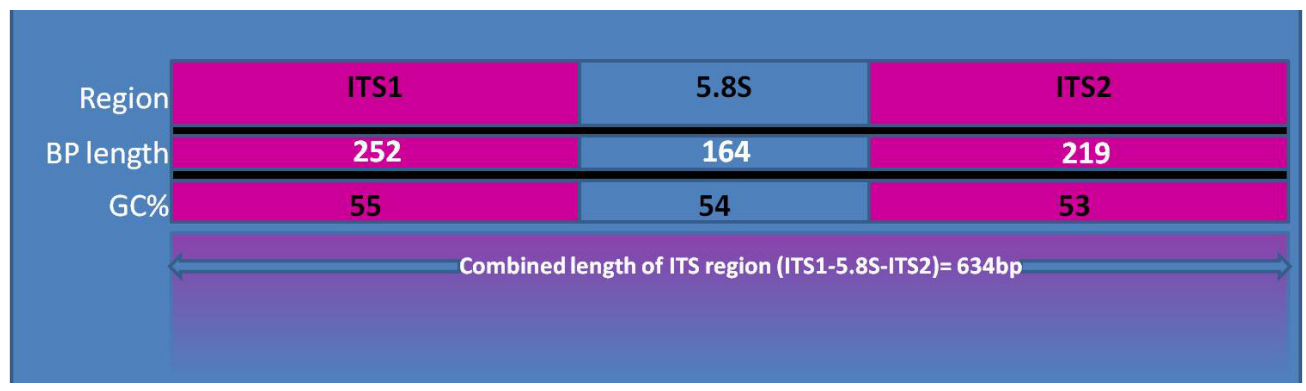

Figure 1. Sequence characteristics of Echinops abuzinadianus.

Table 2. Similarity of internal transcribed spacer (ITS) sequences of Echinops abuzinadianus according to BLAST.

\begin{tabular}{|c|c|c|c|c|c|}
\hline Taxon & Max. score & Total score & Query cover $(\%)$ & Identity (\%) & Accession \\
\hline Echinops glaberrimus & 1129 & 1129 & 100 & 99 & GU116509 \\
\hline E. spinosissimus & 1122 & 1122 & 100 & 99 & HE687348 \\
\hline E. yemenicus & 1123 & 1123 & 100 & 98 & GU116548 \\
\hline E. orientalis & 1120 & 1120 & 100 & 98 & GU116532 \\
\hline E. chardinii & 1120 & 1120 & 100 & 98 & GU116490 \\
\hline E. leucographus & 1118 & 1118 & 100 & 98 & GU116549 \\
\hline E. gaillardotii & 1116 & 1116 & 100 & 98 & GU116507 \\
\hline E. parviflorus & 1114 & 1114 & 100 & 98 & GU116533 \\
\hline E. nitens & 1114 & 1114 & 100 & 98 & GU116529 \\
\hline E. lipskyi & 1110 & 1110 & 100 & 98 & GU116523 \\
\hline E. viscosus & 1110 & 1110 & 100 & 98 & AY826283 \\
\hline E. cornigerus & 1110 & 1110 & 100 & 98 & AY538645 \\
\hline E. griffithianus & 1109 & 1109 & 100 & 98 & GU116512 \\
\hline E. polygamus & 1105 & 1105 & 100 & 98 & GU116534 \\
\hline E. leucographus & 1105 & 1105 & 100 & 98 & GU116522 \\
\hline
\end{tabular}


Parsimony analysis of the entire ITS region resulted in 311 maximally parsimonious trees, with a consistency index of 0.752 , a homoplasy index of 0.457 , and a retention index of 0.756 . There were 526 positions in the final dataset, 101 of which were parsimony-informative. The phylogenetic tree provided clear resolution at the sectional level, with E. abuzinadianus nested within the clade of the section Ritropsis, which confirms the result of a previous study (Sánchez-Jiménez et al., 2010). The ML analysis results were similar, so only the ML topology is discussed hereafter (Figure 2).

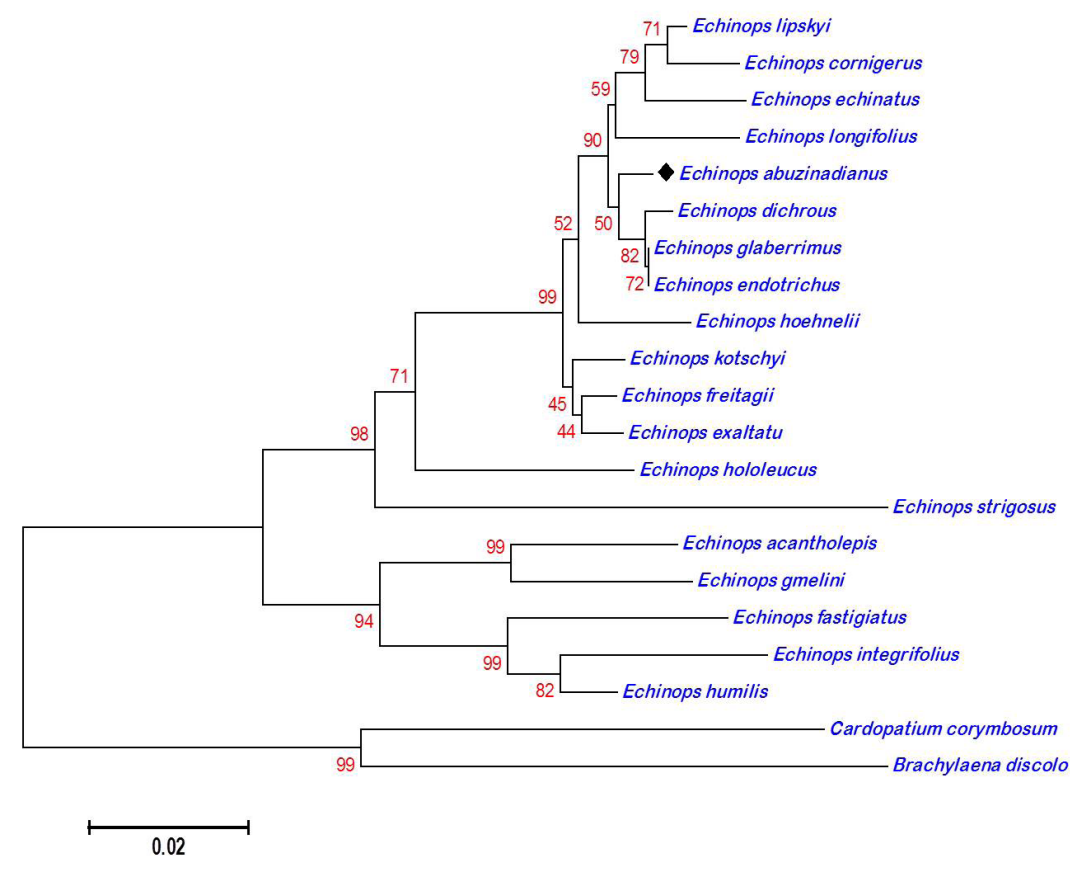

Figure 2. Maximum likelihood tree inferred from analysis of sequence data of the internal transcribed spacer region of nuclear ribosomal DNA.

\section{Molecular typing of $E$. abuzinadianus}

The present study revealed that there were eight nucleotide differences between $E$. abuzinadianus and E. glaberrimus, at alignment positions 60, 61, 66, 81, 188, 226, 441, 552, and 622 (Figure 3 and Table 3). The nrDNA ITS2 secondary structures of E. mandaville $i$ and E. glaberrimus were constructed and compared (Figure 4A and B). The secondary structures of nrDNA ITS2 in these two species contained a central ring (primary ring) and four helices (I, II, III, and IV). The ITS2 secondary structures differed in the four helical regions between the two species in stem loop number, size, position, and screw angle. On the basis of the ITS2 secondary structure, E. abuzinadianus could be distinguished from allied species or other species of the genus. 


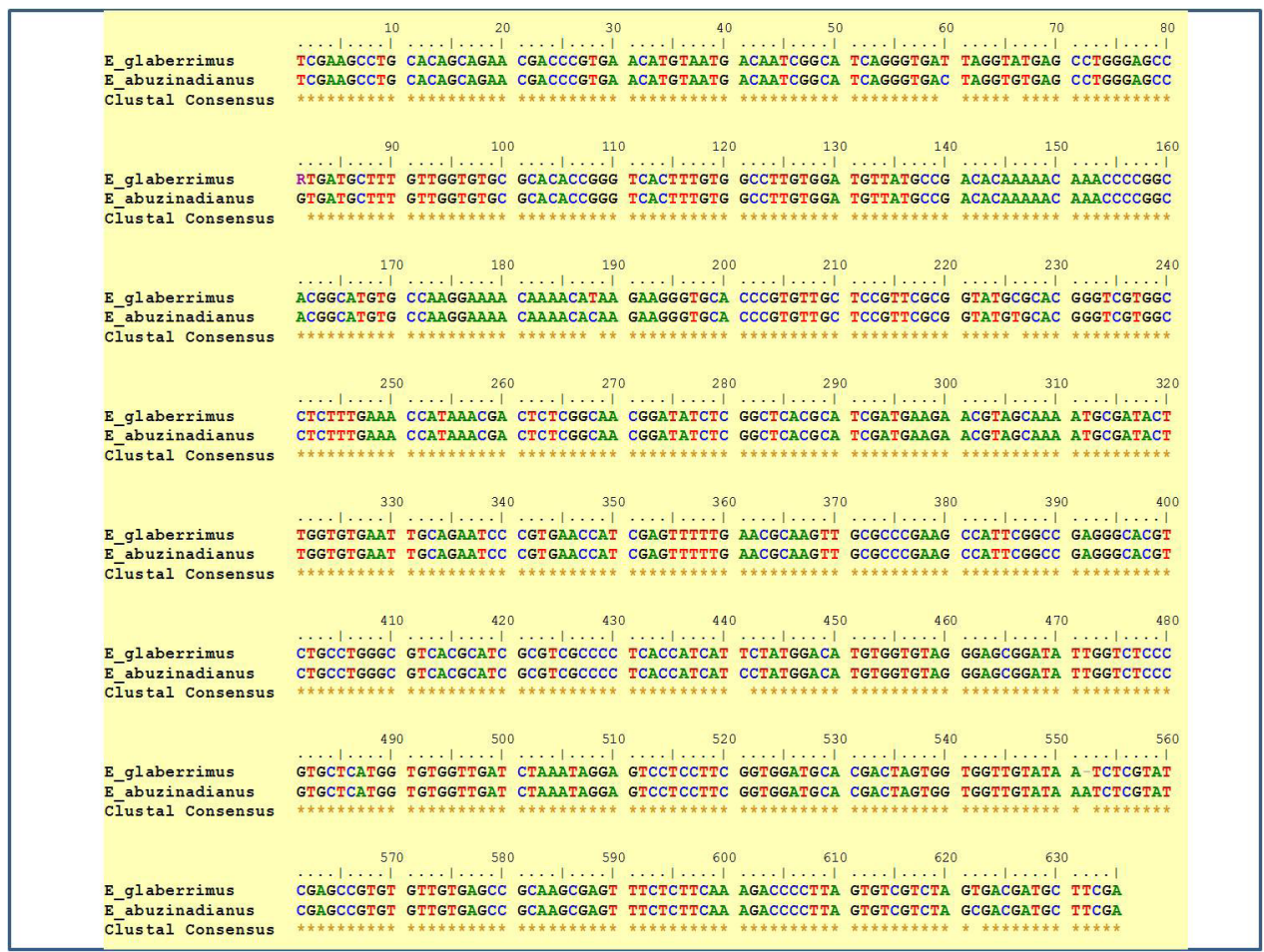

Figure 3. Comparison of ITS sequences of nuclear ribosomal DNA in between Echinops glaberrimus and E. abuzinadianus. Positions without asterisks in the Clustal line denotes the differences in base pairs in between two sequences.

Table 3. Differences in base pairs between the internal transcribed spacer (ITS) sequences of Echinops glaberrimus and E. abuzinadianus.

\begin{tabular}{lcc}
\hline Position in sequence alignment & Echinops glaberrimus & E. abuzinadianus \\
\hline 60 & $\mathrm{~T}$ & $\mathrm{C}$ \\
66 & $\mathrm{~A}$ & $\mathrm{G}$ \\
81 & $\mathrm{R}$ & $\mathrm{G}$ \\
188 & $\mathrm{~T}$ & $\mathrm{C}$ \\
226 & $\mathrm{C}$ & $\mathrm{T}$ \\
441 & $\mathrm{~T}$ & $\mathrm{C}$ \\
552 & - & $\mathrm{A}$ \\
622 & $\mathrm{~T}$ & $\mathrm{C}$ \\
\hline
\end{tabular}

A tandem repeat finder (Benson, 1999) was used to detect repeats in the ITS sequences; differences in substitution rate can discriminate functional genes from pseudogenes (Buckler and Holtsford, 1996a,b). The distribution and pattern of nucleotide substitutions in all of the sequences was investigated using Hypermut (Rose and Korber, 2000). This program was originally designed to study the sequence evolution of HIV, and identifies excessive levels of $\mathrm{G}$ to A mutations. It assumes that all differences arise from a single substitution, and all substitutions observed in each sequence are compared to the reference sequence, and their physical locations in the sequences are graphically illustrated (Figure 5). 


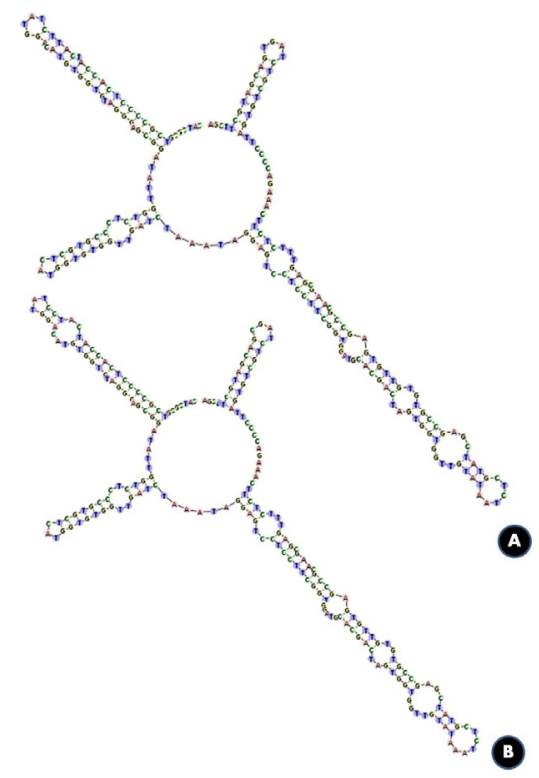

Figure 4. Secondary structures of the ITS2 regions of Echinops abuzinadianus (A) compared to E. glaberrimus (B).

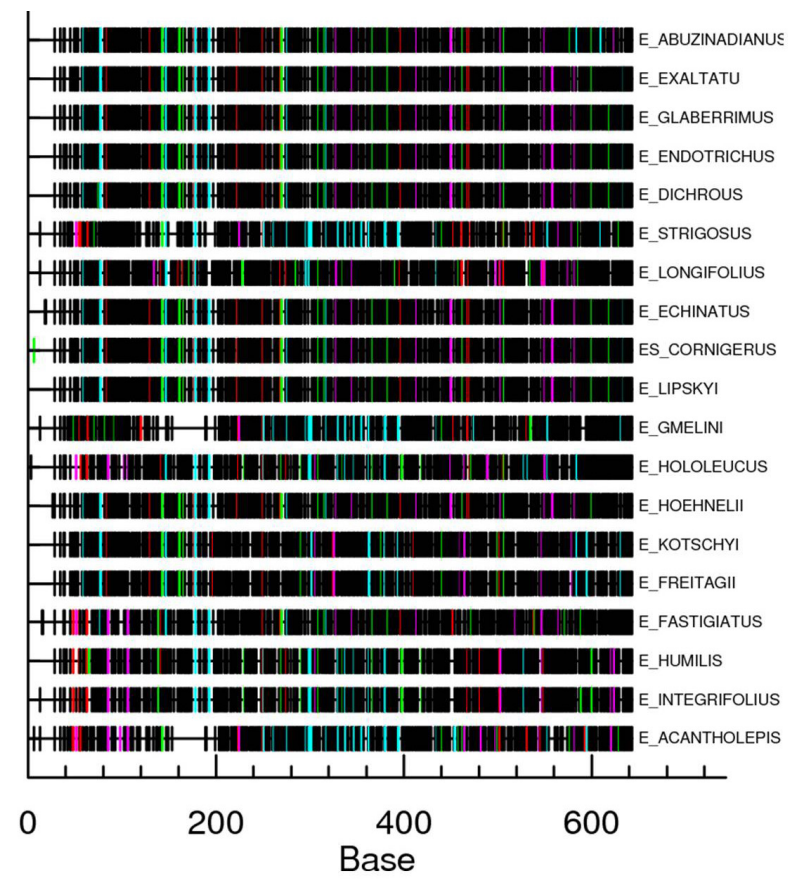

Figure 5. Schematic illustration of the distribution of substitution sites across the ITS region obtained from 20 species of Echinops, using Brachylaena discolor as reference. red $=\mathrm{GG}>\mathrm{AG}$; cyan $=\mathrm{GA}>\mathrm{AA}$; green $=\mathrm{GC}>$ $\mathrm{AC}$; magenta $=\mathrm{GT}>\mathrm{AT}$; black $=$ not $\mathrm{G}>\mathrm{A}$ transition; yellow $=$ gap. 


\section{DISCUSSION}

Morphological identification depends on sufficient experience, and can easily be affected by geographical environment and biocoenosis (Rai et al., 2012). DNA barcode technology is widely used, because the genomic sequence is little affected by individual characteristics and developmental stages, and it is relatively a simple procedure (Liu et al., 2011); therefore, DNA barcoding is an effective supplement to traditional/classical morphological methods. Species identification using DNA barcodes has been successfully used across all plant and animal groups. Plant DNA barcoding is now changing over the essence of species identification, and consequently is contributing to the molecularization of taxonomy. DNA barcodes provide practical, standardized, species-level identification tools that can be used for biodiversity assessment, life history and ecological studies, and forensic analysis (Ali and Choudhary, 2011; Ali et al., 2014). Global DNA barcoding efforts have resulted in the formation of the Consortium for the Barcode of Life (CBOL). The Barcode of Life Database (BOLD) contains more than 2.7 million specimen records, with 2 million having barcodes of over 170,000 species (Ratnasingham and Hebert, 2007). In the present study, we used the ITS region of nuclear ribosomal DNA for the DNA barcoding of E. abuzinadianus. The primary sequences of ITS, as well as the secondary structures of ITS2, provided sufficient molecular morphological characteristics to distinguish E. abuzinadianus from other species of the genus. Recently, a number of studies have suggested that DNA secondary structures are crucial for genomic stability and cellular processes, such as transcription (Bochman et al., 2012; Salvi and Mariottini, 2012). The ITS2 region has also been confirmed as a novel barcode for identifying medicinal plant species (Chen et al., 2010; Gao et al., 2010; Yao et al., 2010; Song et al., 2012); this study has expanded the application of the secondary structure of the ITS2 region as a molecular signature for species identification. The China Plant BOL Group has proposed that ITS/ITS2 should be incorporated into the core barcode for seed plants (Li et al., 2011), and the present study has broadened the application of the ITS2 region to $E$. abuzinadianus in particular.

\section{ACKNOWLEDGMENTS}

The authors would like to extend their sincere appreciation to the Deanship of Scientific Research at King Saud University for its funding of this research through the research group project \#RGP-VPP-195.

\section{REFERENCES}

Al-Hemaid FMA, Ali MA, Lee J, Gyulai G, et al. (2014). Application of internal transcribed spacer of nuclear ribosomal DNA for identification of Echinops mandavillei Kit Tan. Bangladesh J. Plant Taxon. 21: 33-42.

Ali MA and Choudhary RK (2011). India needs more plant taxonomists. Nature 471: 37.

Ali MA, Al-Hemaid FM, Choudhary RK, Lee J, et al. (2013). Status of Reseda pentagyna Abdallah \& A.G. Miller (Resedaceae) inferred from combined nuclear ribosomal and chloroplast sequence data. Bangladesh J. Plant Taxon. 20: 233-238.

Ali MA, Gyulai G, Hidvégi N, Kerti B, et al. (2014). The changing epitome of species identification - DNA barcoding. Saudi J. Biol. Sci. 21: 204-231.

Baldwin BG (1992). Phylogenetic utility of the internal transcribed spacers of nuclear ribosomal DNA in plants: an example from the Compositae. Mol. Phylogenet. Evol. 1: 3-16. 
Benson G (1999). Tandem repeats finder: a program to analyze DNA sequence. Nucleic Acids Res. 27: 573-580.

Bobrov EG (1997). Echinops L. In: Flora of the USSR (Shishkin BK and Bobrov EG, eds.). Koeltz Scientific Books, Koenigstein, 27: 1-70.

Bochman ML, Paeschke K and Zakian VA (2012). DNA secondary structures: stability and function of G-quadruplex structures. Nat. Rev. Genet. 13: 770-780.

Buckler ES and Holtsford TP (1996a). Zea ribosomal repeat evolution and mutation patterns. Mol. Biol. Evol. 13: 623-632.

Buckler ES and Holtsford TP (1996b). Zea systematics: ribosomal ITS evidence. Mol. Biol. Evol. 13: 612-622.

Chaudhary S (2000). Echinops. In: Flora of the Kingdom of Saudi Arabia (Chaudhary S, ed.). Ministry of Agriculture and Water, National Herbarium, National Agriculture and Water Research Center, Riyadh, Vol. II (3): 194-199.

Chen S, Yao H, Han J, Liu C, et al. (2010). Validation of the ITS2 region as a novel DNA barcode for identifying medicinal plant species. PLoS One 5: e8613.

Gao T, Yao H, Song J, Liu C, et al. (2010). Identification of medicinal plants in the family Fabaceae using a potential DNA barcode ITS2. J. Ethnopharmacol. 130: 116-121.

Garnatje T, Susanna A, Garcia-Jacas N, Vilatersana R, et al. (2005). A first approach to the molecular phylogeny of the genus Echinops L. (Asteraceae): Sectional delimitation and relationships with the genus Acantholepis Less. Folia Geobot. 40: 407-419.

Hall TA (1999). BioEdit: a user-friendly biological sequence alignment editor and analysis program for Windows 95/98/ NT. Nucleic Acids Symp. Ser. 41: 95-98.

Hidalgo O, Garcia-Jacas N, Garnatje T, Susanna de la Serna A, et al. (2006). Phylogeny of Rhaponticum (Asteraceae, Cardueae-Centaureinae) and related genera inferred from nuclear and chloroplast DNA sequence data: Taxonomic and biogeographic implications. Ann. Bot. 97: 705-714.

Jäger EJ (1987). Arealkarten der Asteraceen-Tribus als Grundlage der ökogeographischen Sippencharakteristik. Bot. Jahrb. Syst. 108: 481-497.

Koetschan C, Hackl T, Müller T, Wolf M, et al. (2012). ITS2 database IV: interactive taxon sampling for internal transcribed spacer 2 based phylogenies. Mol. Phylogenet. Evol. 63: 585-588.

Li DZ, Gao LM, Li HT, Wang H, et al. (2011). Comparative analysis of a large dataset indicates that internal transcribed spacer (ITS) should be incorporated into the core barcode for seed plants. Proc. Natl. Acad. Sci. U. S. A. 108: 1964119646.

Liu C, Liang D, Gao T, Pang X, et al. (2011). PTIGS-IdIt, a system for species identification by DNA sequences of the psbA-trn $\mathrm{H}$ intergenic spacer region. BMC Bioinformatics 12: $\mathrm{S} 4$.

Mozaffarian V (2006). A taxonomic survey of Echinops L. tribe Echinopeae (Asteraceae) in Iran: 14 new species and diagnostic keys. Iran. J. Bot. 11: 197-239.

Petit DP (1988). Le genre Echinops L. (Compositae: Cardueae). 1. Position phylétiqueetinterprétation de l'incapitulescence. Candollea 43: 467-481

Rai PS, Bellampalli R, Dobriyal RM, Agarwal A, et al. (2012). DNA barcoding of authentic and substitute samples of herb of the family Asparagaceae and Asclepiadaceae based on the ITS2 region. J. Ayurveda Integr. Med. 3: 136-140.

Ratnasingham S and Hebert PDN (2007). BOLD: The barcode of life data system (http://www.barcodinglife.org). Mol. Ecol. Notes 7: 355-364.

Rose PP and Korber BT (2000). Detecting hypermutations in viral sequences with an emphasis on G A hypermutation. Bioinformatics 16: 400-401.

Salvi D and Mariottini P (2012). Molecular phylogenetics in 2D: ITS2 rRNA evolution and sequence-structure barcode from Veneridae to Bivalvia. Mol. Phylogenet. Evol. 65: 792-798.

Sánchez-Jiménez I, Lazkov GA, Hidalgo O, Garnatje T, et al. (2010). Molecular systematics of Echinops L. (Asteraceae, Cynareae): A phylogeny based on ITS and $\operatorname{trn} \mathrm{L}-\operatorname{trn} \mathrm{F}$ sequences with emphasis on sectional delimitation. Taxon 59: 698-708.

Song J, Shi L, Li D, Sun Y, et al. (2012). Extensive pyrosequencing reveals frequent intra-genomic variations of internal transcribed spacer regions of nuclear ribosomal DNA. PLoS One 7: e43971.

Susanna A and Garcia-Jacas N (2007). The tribe Cardueae. In: The families and genera of vascular plants. Flowering plants; Eudicots; Asterales (Kadereit JW and Jeffrey C, eds.). Springer, Heidelberg, 8: 135-158.

Susanna A, Garnatje T and Garcia-Jacas N (1999). Molecular phylogeny of Cheirolophus (Asteraceae: CardueaeCentaureinae) based on ITS sequences of nuclear ribosomal DNA. Plant. Syst. Evol. 214: 147-160.

Susanna A, Garcia-Jacas N, Hidalgo O, Vilatersana R, et al. (2006). The Cardueae (Compositae) revisited: Insights from ITS, trnL-trnF, and matK nuclear and chloroplast DNA analysis. Ann. Missouri Bot. Gard. 93: 150-171.

Tamura K, Peterson D, Peterson N, Stecher G, et al. (2011). MEGA5: molecular evolutionary genetics analysis using maximum likelihood, evolutionary distance, and maximum parsimony methods. Mol. Biol. Evol. 28: 2731-2739.

Thompson JD, Gibson TJ, Plewniak F, Jeanmougin F, et al. (1997). The CLUSTAL X windows interface: flexible strategies 
for multiple sequence alignment aided by quality analysis tools. Nucleic Acids Res. 25: 4876-4882.

Vilatersana R, Susanna A, Garcia-Jacas N, Garnatje T, et al. (2000). Generic delimitation and phylogeny of the Carduncellus-Carthamus complex (Asteraceae) based on ITS sequences. Plant. Syst. Evol. 221: 89-105.

Wang YJ, Pan JT, Liu SW, Liu JQ, et al. (2005). A new species of Saussurea (Asteraceae) from Tibet and its systematic position based on ITS sequence analysis. Bot. J. Linn. Soc. 147: 349-356.

Wang YJ, Liu JQ and Miehe G (2007). Phylogenetic origins of the Himalayan endemic Dolomiaea, Diplazoptilon and Xanthopappus (Asteraceae: Cardueae) based on three DNA regions. Ann. Bot. 99: 311-322.

White TJ, Bruns T, Lee S and Taylor J (1990). Amplification and direct sequencing of fungal ribosomal RNA genes for phylogenetics. In: PCR protocols: a guide to method and amplifications (Innis MA, Gelfand DH, Sninksky JJ and White TJ, eds.). Academic Press, San Diego, 315-322.

Yao H, Song J, Liu C, Luo K, et al. (2010). Use of ITS2 region as the universal DNA barcode for plants and animals. PLoS One 5: e13102. 